\title{
STRATEGI PERSIAPAN PENGAJUAN IJIN OPERASIONAL DI TPA BRIGHT MINDS SALATIGA
}

\author{
${ }^{1}$ Catharina Lesananingtyas \\ Program Studi S1 Pendidikan Guru Pendidikan Anak Usia Dini \\ FKIP- Universitas Kristen Sayta Wacana \\ 272014015@student.uksw.edu \\ ${ }^{2}$ Lanny Wijayaningsih \\ Program Studi S1 Pendidikan Guru Pendidikan Anak Usia Dini \\ FKIP- Universitas Kristen Sayta Wacana \\ Lanny.Wijayaningsih@yahoo.com \\ ${ }^{3}$ Mozes Kurniawan \\ Program Studi S1 Pendidikan Guru Pendidikan Anak Usia Dini \\ FKIP- Universitas Kristen Sayta Wacana \\ mozes.kurniawan@staff.uksw.edu
}

\begin{abstract}
The objective of thisresearch is to find out about the operational requirements of a Daycare Center (TPA) in order to help the TPA Bright Minds Salatiga getting its operational permit. The nature of this research is descriptive qualitative. Subjects of the study are the TPA Bright Minds Management and the Caregivers. Data is collected using observations, documentations, and deep interview methods. The collected data isanalyzed using techniques of data reduction, data presentation and verification. The results showed that there are two main categories of operational requirements, i.e. adminstrative and technical requirements. The administrative requirements include submision of TPA founder identity, certificate of domicile from the local headman, structure and detailed role of each of the Board members. The technical requirements are legal and valid documents of ownership/leasing rights of the land and buildings, estimated operational costs of the TPA, plan of TPA implementation standards, and some other additional documents. Thus, based on study's results, it is to suggest that the TPA Bright Minds Salatiga, should immediately strategize an application of its operational permit to the authorities.
\end{abstract}

Keywords: Daycare Center (TPA), TPA operational requirements, Operational Permits 


\section{PENDAHULUAN}

\section{Latar Belakang}

Menurut Apriliia (2015), Layanan Taman Penitipan Anak (TPA) adalah suatu pendidikan nonformal bagi Anak Usia Dini (AUD), bertujuan untuk membantu orang tua yang mempunyai kesibukan dalam bekerja dengan memberikan pengasuhan kepada anak. Dengan demikian, TPA memberikan suatu layanan pengasuhan bagi anak pada saat orang tua sibuk bekerja dengan menjaga anak-anak dan memberikan stimulasi serta pendidikan yang sesuai dengan tahap perkembangan anak. Menurut petunjuk teknis penyelenggaraan Taman Penitipan Anak (TPA), bahwa dalam pendirian Taman Penitipan Anak (TPA) dapat melalui kepala dinas pendidikan kabupaten/kota, pendiri TPA mengajukan permohonan izin pendirian lembaga tesebut kepada kepala dinas pendidikan kabupaten/kota atau kepala Satuan Kerja Perangkat Daerah (SKPD) dengan melampirkan persyaratan pendirian TPA. Menurut UU No 20 tahun 2003 tentang Sistem Pendidikan Nasional, pasal 62 ayat (1) setiap satuan pendidikan formal dan non formal yang didirikan wajib memperoleh izin pemerintah atau pemerintah daerah.

Pihak lembaga akan memperoleh perlindungan dari pemerintah apabila sudah memiliki ijin operasional. Namun, apabila lembaga belum memiliki ijin operasional dapat berdampak negatif seperti tidak diakuinya oleh pemerintah dan tidak memperoleh perlindungan dari pemerintah. Seperti yang terjadi pada salah satu TK di Jakarta Utara, Sekolah Saint Monica, yang mana belum memiliki izin. Berdasarkan Liputan6.com, "Sekolah Saint Monica, merupakan taman kanak-kanak menurut instrumen kelengkapan izin operasionalnya, lembaga tersebut memberikan layanan playgroup akan tetapi belum memiliki izin operasional," kata Kepala Suku Dinas Pendidikan Menengah Jakarta Utara Mustafa Kemal di Sekolah Saint Monica, Sunter, Jumat (16/5/2014). Surat penghentian kegiatan itu efektif mulai berlaku hari ini. "Saya memerintahkan Yayasan Pendidikan Mulia Bakti menghentikan kegiatan playgroup terhitung tanggal 16 Mei 2014," imbuhnya. Berasarkan surat pemberhetian tersebut, diberikan saran untuk yayasan supaya peserta didik disalurkan ke lembaga pendidikan anak usia dini terdekat atau dapat diserahkan kepada pihak orangtua.

Berdasarkan contoh kasus di Sekolah Saint Monica Jakarta Utara tersebut, maka kelengkapan izin operasional menjadi hal yang perlu diperhatikan bagi suatu lembaga sekolah. Namun, hal ini juga belum diperhatikan oleh salah satu lembaga Taman Penitipan Anak (TPA) yang ada di Salatiga, yaitu TPA Bright Minds. Taman Penitipan Anak yang berdiri pada tahun 2012 ini berlokasi di Jln. Hasanudin 134 Salatiga. Taman Penitipan Anak (TPA) ini milik perseorangan yang bangunannya menyewa gedung milik Sekolah Tinggi Jemaat Kristus Indonesia. Akan tetapi, Taman Penitipan Anak (TPA) ini belum memenuhi persyaratan administratif pendirian Taman Penitipan Anak (TPA), dan persyaratan teknis pendirian Taman Penitipan Anak (TPA). 
"Ya bagaimana ya mbak..saya mendirikan ini ya hanya berjalan dulu. Karena ya dulu ada yang mau membantu soal perijinan. Tapi ya sampai sekarang belum ada. Yang saya takutkan itu kedepannya bagaimana, jika tidak memiliki surat ijin pendirian. Karena ya saya ini ingin supaya aman TPA ini memiliki surat ijin. Kalau ada surat ijin kan setidaknya sudah aman. Tapi saya juga bingung harus minta kemana dan apa saja yang disiapkan (sambil tersenyum)." (Rt).

Menurut hasil observasi di lapangan, pihak Bright Minds Salatiga belum memiliki surat perijinan operasional Taman Penitipan Anak (TPA). Kendala yang dihadapi TPA Bright Minds Salatiga ini yaitu belum mengetahui kelengkapan persyaratan yang diperlukan untuk memiliki surat ijin pendirian Taman Penitipan Anak (TPA) dan belum mengajukan kepada Dinas Pendidikan. Pengelola TPA Bright Minds Salatiga mengalami kesulitan dalam mempersiapkannya. Dengan demikian, penulis ingin membantu pihak TPA Bright Minds untuk menyusun dan mempersiapkan ijin operasional.

\section{Rumusan Masalah}

Bagaimana rencana strategi dalam mempersiapkan pengajuan ijin operasional di TPA Bright Minds Salatiga?

\section{Tujuan dan Manfaat Penelitian}

Dalam penelitian ini bertujuan untuk mengetahui dan mempersiapkan pengajuan ijin operasional di TPA Bright Minds Salatiga. Manfaat pada penelitian ini yaitu:

a. Manfaat teoritis

Dapat memberi sumbangan ilmiah bagi wawasan pendidikan prasekolah terutama di Taman Penitipan Anak (TPA) dalam rangka mempersiapkan pengajuan ijin operasional di TPA.

b. Manfaat praktis

Penelitian ini diharapkan memberi informasi kepada masyarakat, terutama bagi pendiri TPA tentang perijinan Taman Penitipan Anak (TPA) di Bright Minds Salatiga. Disamping itu penelitian ini dapat memberikan masukan dan manfaat bagi TPA yang lain.

\section{KAJIAN TEORI}

Secara etimologi strategi merupakan suatu kata yang berarti strategos menurut bahasa Yunani. Pada zaman demokrasi Athena mengartikan strategos yaitu "komandan militer". Menurut David Hunger dan Thomas L. Wheelen (2003), strategi merupakan suatu tindakan yang diambil/ diputuskan dan tindakan untuk memperbaiki suatu lembaga yang dijadikan kinerja suatu lembaga dalam jangka waktu yang panjang. Strategi menurut Anwar Arifin (1984), merupakan suatu kepuasan kondisional mengenai tindakan yang akan dilaksanakan yang berguna untuk mencapai tujuan. Berdasarkan beberapa pendapat yang telah dijelaskan, dapat ditarik kesimpulan bahwa untuk mencapai tujuan atau target yang diinginkan diperlukan adanya strategi yang merupakan upaya yang dilakukan melalui suatu tahapan-tahapan tertentu. Menurut Chandler dalam buku Analisis SWOT Teknis Membedah Kasus Bisnis, Rangkuti (2013:3-4) Strategi adalah alat yang digunakan untuk mencapai 
tujuan suatu lembaga yang berkaitan dengan tujuan jangka panjang, program tindak lanjut, dan prioritas alokasi sumber daya.

Kata izin, menurut Kamus Besar Bahasa Indonesia (Departemen Pendidikan dan Kebudayaan, 1989: 341), Izin merupakan pernyataan mengabulkan (tidak ada larangan dsb); persetujuan memperbolehkan. Menurut Mukhlis (2014), ijin operasional merupakan surat permohonan dari pendiri atau pengelola sekolah kepada pemerintah terkait supaya sekolah yang didirikan memperoleh ijin. Tujuan dari ijin ini supaya segala kegiatan terkait sekolah merupakan kegiatan yang sah dan legal dimata hukum, serta dapat memperoleh kepercayaan terhadap masyarakat yang akan menyekolahkan atau menitipkan anaknya pada lembaga PAUD terkait. Menurut UU No 44 tahun 2006 pasal 6 ayat 1, satuan pendidikan non-formal akan memperoleh bantuan apabila memiliki ijin pendirian dari pejabat yang berwenang.

Pendidikan Anak Usia Dini merupakan tempat bermain sambil belajar yang penuh dengan keceriaan. Sehingga anak dapat mengembangkan bakat, potensi, minat dan kreatifitasnya. Selain itu anak dapat memperoleh pengetahuan keterampilan dan pengembangan sikap dalam suasana yang menyenengkan (Suharti, 2018). Taman Penitipan Anak (TPA) merupakan sebuah lembaga yang dirintis sejak tahun 1963 oleh Departemen Sosial yang bertujuan untuk memenuhi kebutuhan pengasuhan, pembinaan, sosialisasi anak dengan lingkungan, bimbingan selama anak tidak bersama orangtua (Syamsuddin, 2015). Menurut Kusumawati (2017) Taman Penitipan Anak (TPA) mampu menjawab kebingungan orangtua yang keduanya bekerja. Manfaat yang akan didapatkan orangtua yang menitipkan anaknya di TPA yaitu anak akan belajar bersosialisasi dengan teman-temannya, anak akan memperoleh pengetahuan, pembelajaran dan keterampilan untuk meningkatkan bakat yang dimiliki anak. Menurut Patmonodewo (2003) Taman Penitipan Anak (TPA) merupakan sebuah lembaga yang berupaya untuk memberikan pengasuhan kepada anak-anak selama beberapa jam dalam satu hari dan telah terorganisasi. Taman Penitipan Anak (TPA) dapat berperan sebagai pengganti keluarga bagi anak yang orang tuanya tidak dapat mengasuh dikarenakan suatu halangan dalam suatu waktu tertentu (bekerja, sakit atau halangan yang lain sehingga tidak dapat memenuhi kebutuhan anak), dengan adanya penyelenggaraan pengasuhan dan pendidikan prasekolah bagi anak usia 0-6 tahun. TPA memiliki prinsip filsafat pendidikan yang dirumuskan menjadi: Tempa, Asah, Asih, Asuh (Dirjen PAUDNI, 2013: 19). Prisip tersebut dilaksanakan supaya mendukung mewujudkan anak usia dini yang berkualitas, maju, mandiri, demokrasi, dan berprestasi. Tempa adalah suatu upaya pemeliharaan kesehatan dan aktivitas jasmani agar dapat mencapai serta mewujudkan kualitas fisik anak usia dini. Asah adalah upaya mengembangkan seluruh potensi yang dimiliki setiap anak agar memiliki pengalaman yang berguna dengan memberikan suatu dukungan untuk anak supaya dapat belajar melalui bermain. Asih merupakan perlindungan untuk anak dari pengaruh yang dapat menggangu pertumbuhan dan perkembangan anak, dengan upaya menjamin pemenuhan kebutuhan anak. Asuh merupakan pembentukan perilaku dan kualitas kepribadian serta jati diri pada anak dengan sikap pembiasaan yang dilakukan secara konsisten.

Yang dapat mendirikan Taman Penitipan Anak (TPA) menurut petunjuk teknis penyelenggaraan Taman Penitipan Anak (TPA), yaitu:

a. Pemerintah kabupaten/kota. 
b. Pemerintah desa.

c. Orang perseorangan.

d. Kelompok orang.

e. Badan hukum.

TPA Bright Minds Salatiga merupakan salah satu TPA yang didirikan oleh orang perseorangan. Orang perseorangan adalah warga negara Indonesia yang paham terhadap hukum yang berpedoman pada ketentuan peraturan perundang-undangan. Dalam merencanakan pendirian sebuah lembaga PAUD supaya teratur harus dimulai dari pemahaman mengenai bagaimana cara lembaga tersebut didirikan (Dr Hapidin, M.Pd). Dalam hal ini, pendirian TPA membutuhkan pemahaman mengenai beberapa syarat yang harus dipenuhi untuk memperoleh ijin pendirian.

Menurut Dinas Pendidikan (2018) Sistem Mekanisme dan Prosedur Pelayanan Ijin Operasional Satuan PAUD yaitu (1) Lembaga mengantarkan surat permohonan dan berkas persyaratan (Ijin Baru / Perpanjangan Ijin), (2) Petugas Menerima Berkas Pemohon, (3) Verifikasi dari Unsur Bidang PAUD dan Penilik PAUD, (4) Penilik Membuat Surat Rekomendasi, (5) Petugas Mencetak Surat/Sertifikat Ijin Operasional / Perpanjangan Ijin, (6) Registrasi Surat/ Ijin Operasional (Paraf Kasi, Kabid dan Sekretaris Dinas Kepala Dinas Pendidika), (7) Arsip.

Menurut Peraturan Menteri Pendidikan dan Kebudayaan Repuplik Indonesia No. 84 tahun 2014 tentang Pendirian Satuan Pendidikan Anak Usia Dini, persyaratan penyelenggaraan TPA terdiri dari persyaratan administratif dan persyaratan teknis, yaitu:

1. Persyaratan administratif penyelenggaraan TPA, yaitu:

a. Fotokopi identitas pendiri.

b. Surat keterangan domisili dari kepala desa/lurah.

c. Susunan pengurus dan rincian tugas.

2. Persyaratan teknis penyelenggaraan TPA yaitu:

a. Hasil penilaian kelayakan, meliputi:

1) Dokumen hak milik, sewa atau pinjam pakai atas tanah dan bangunan yang akan digunakan sebagai penyelenggaraan TPA yang sah atas nama pendiri

2) Dalam hal pendiri adalah badan hukum, wajib melampirkan fotokopi akta notaris dan surat penetapan badan hukum dalam bentuk yayasan, perkumpulan, atau badan lain sejenis dari kementerian bidang hukum atas nama pendiri atau induk organisasi pendirik disertai surat keputusan yang menunjukkan adanya hubungan dengan organisasi induk

3) Data mengenai perkiraan pembiayaan untuk kelangsungan TPA paling sedikit untuk 1 (satu) tahun pembelajaran.

b. Dokumen rencana pencapaian standar penyelenggaraan TPA paling lama 5 tahun, yang sesuai dengan Peraturan Menteri Pendidikan dan Kebudayaan Repuplik Indonesia No. 137 tahun 2014 tentang Standar Nasional Pendidikan Anak Usia Dini.

Mekanisme pendirian TPA menurut Menteri Pendidikan dan Kebudayaan Repuplik Indonesia No. 84 tahun 2014 tentang Pendirian Satuan Pendidikan Anak Usia Dini, yaitu:

1) Pendiri TPA mengajukan permohonan izin penyelenggaraan TPA kepada kepala dinas.

2) Pendidikan kabupaten/kota atau kepala Satuan Kerja Perangkat Daerah. 
3) (SKPD) melalui kepala dinas pendidikan kabupaten/kota dengan melampirkan persyaratan penyelenggaraan TPA.

4) Kepala dinas pendidikan kabupaten/kota atau pejabat yang ditunjuk memeriksa permohonan penyelenggaraan TPA berdasarkan kelengkapan persyaratan pemohon dengan memperhatikan hal-hal sebagai berikut:

a. Data mengenai perimbangan antara jumlah TK/TKLB, KB, TPA, dan/atau SPS yang telah ada dan yang akan didirikan dengan jumlah penduduk usia sasaran yang akan dilayani di wilayah tersebut.

b. Data mengenai perkiraan jarak TPA yang akan didirikan di antara TK/TKLB, KB, TPA, dan/atau SPS terdekat.

c. Data mengenai daya tampung dan lingkup jangkauan TPA yang akan didirikan per usia yang dilayani.

d. Ketentuan penyelenggaraan TPA ditetapkan oleh pemerintah provinsi dan/atau pemerintah kabupaten/kota.

5) Berdasarkan hasil pemeriksaan kepala dinas pendidikan kabupaten/kota:

a. Berwenang memberikan persetujuan atau penolakan atas permohonan izin penyelenggaraan TPA; atau

b. Berwenang memberikan rekomendasi kepada kepala SKPD atas permohonan izin penyelenggaraan TPA.

6) Kepala dinas pendidikan kabupaten/kota atau kepala SKPD menerbitkan keputusan izin penyelenggaraan TPA maksimal 60 hari sejak permohonan diterima kepala dinas.

Dasar Hukum Pendirian Taman Penitipan Anak (TPA) menurut Dinas Pendidikan Kota Salatiga yaitu:

1. Peraturan Menteri Pendidikan dan Kebudayaan Nomor 84 tahun 2014 tentang Pendirian Satuan Pendidikan Anak Usia Dini

2. Keputusan Kepala Disidikpora Kota Salatiga Nomor 800/0514/101, tanggal 2 November 2016 tentang Penerapan Standar Operasional Prosedur (SOP) Pelayanan Perizinan Pendidikan Non Formal pada Dinas Pendidikan Pemuda dan Olahraga Kota Salatiga

\section{METODE PENELITIAN}

\section{Jenis Penelitian}

Penelitian ini adalah jenis penelitian deskriptif kualitatif. Metode penelitian kualitatif yaitu metode penelitian yang bertujuan untuk meneliti suatu kondisi obyek alamiah, peneliti sebagai instrumen kunci, teknik pengumpulan dengan trianggulasi (gabungan), yang berlandasakan pada filsafat postpositivisme analisis data bersifat induktif/ kualitatif, dan hasil penelitian kualitatif lebih menekankan makna daripada generalisasi (Sugiyono, 2010).

\section{Tempat dan Subjek Penelitian}

Tempat yang digunakan sebagai penelitian adalah Taman Penitipan Anak (TPA) Bright Minds Salatiga yang berlokasi di Jln. Hasanudin 134 Salatiga. Penelitian ini dilaksanakan pada bulan September 2017 sampai dengan bulan Desember 2017. Subjek 
penelitian merupakan subjek sebagai narasumber yang dituju oleh peneliti untuk diteliti. Subjek sasaran penelitian ini adalah pengelola dan pendidik TPA Bright Minds Salatiga.

\section{Instrumen Penelitian dan Teknik Pengumpulan Data}

Arikunto (2005) mengatakan bahwa supaya dapat mengumpulkan data menjadi sistematis maka peneliti dapat menggunakan alat bantu yang disebut instrumen penelitian. Peneliti itu sendiri menggunakan instrumen penelitian pada penelitian kualitatif deskriptif ini (instrumen penelitian atau manusia sebagai alat bantu). Pedoman wawancara dan pedoman observasi dapat membantu untuk mempermudah proses pengumpulan data. Teknik pengumpulan data yang digunakan dalam penelitian ini menggunakan: (1) Wawancara, Moleong (2007) mengatakan bahwa wawancara merupakan kegiatan tanya jawab dengan maksud dan tujuan tertentu. Kegiatan tanya jawab tersebut dilakukan dua pihak yaitu yang memberikan pertanyaan disebut pewawancara dan yang memberikan jawaban yaitu terwawancara disebut sebagai narasumber. (2) Observasi, Burhan Bungin (2007) mengatakan bahwa, observasi adalah suatu kegiatan yang bertujuan untuk memperoleh informasi yang dibutuhkan sebagai jawaban atas masalah penelitian, dengan memanfaatkan panca indera. Metode ini digunakan untuk memperoleh data tentang Persiapan Pengajuan Ijin Operasional di TPA Bright Minds Salatiga. Dalam hal ini peneliti tidak mengubah data dan situasi di TPA Bright Minds. Data-data atau informasi yang diperoleh melalui pengamatan kemudian dituliskan menjadi suatu tulisan. Dalam kegiatan observasi, peneliti membawa buku catatan untuk mencatat hal-hal atau informasi yang mendukung dalam penelitian. Observasi dilakukan untuk menyimpulkan data tentang Persiapan Pengajuan Ijin Operasional di TPA Bright Minds Salatiga. (3) Dokumentasi, dokumentasi yaitu kegiatan untuk memperoleh informasi mengenai hal-hal yang berupa catatan, transkrip, buku, surat kabar, majalah (Suharsimi Arikunto, 2004). Pada bagian ini jenis data yang diperoleh dijelaskan dalam katakata dan tindakan, sumber data tertulis dan foto. Metode dokumentasi dilakukan karena dapat mendukung dalam pengungkapan sesuatu kejadian yang dapat didokumentasikan.

Uji keabsahan data dalam penelitian kualitatif menurut Sugiyono (2010) meliputi uji credibility (validityas interbal), transferability (validitas eksternal), dependability (reliabilitas), dan confirmability (obyektivitas). Penelitian ini menggunakan uji kredibilitas untuk menguji keabsahan data. Uji kredibilitas data dilakukan melalui triangulasi. Triangulasi data yaitu pengecekan data dari sumber-sumber yang diperoleh dengan beberapa cara dan beberapa waktu. Dalam keabsahan data, ada 3 triangulasi, yaitu triangulasi sumber, triangulasi teknik dan triangulasi waktu.

\section{HASIL PENELITIAN DAN PEMBAHASAN}

Pengumpulan data penelitian dilakukan dengan wawancara kepada subjek dan informan. Subjek sekaligus informan dalam penelitian ini adalah pemilik lembaga TPA itu sendiri. Temuan penelitian secara individual adalah sebuah rangkuman data yang berisikan tulisan atau fakta-fakta yang didapatkan selama proses wawancara dan observasi pada subjek. Berdasarkan hasil wawancara dengan subjek, tampak bahwa subjek belum menyusun semua dokumen-dokumen yang di perlukan untuk memenuhi persyaratan pengajuan ijin operasional. 
Tabel 1. Syarat Pengajuan Ijin Operasional Pendidikan Non-formal

\begin{tabular}{|c|c|c|}
\hline $\begin{array}{l}\text { Indikator } \\
\text { Persyara-tan }\end{array}$ & $\begin{array}{l}\text { Kendala yang dihadapi } \\
\text { lembaga }\end{array}$ & Tindakan/ Strategi yang dilakukan \\
\hline Surat Permohonan & $\begin{array}{l}\text { Belum dapat menyusun } \\
\text { surat permohonan, } \\
\text { dikarenakan pengelola } \\
\text { masih menyelesaikan } \\
\text { dokumen yang lain. }\end{array}$ & $\begin{array}{l}\text { Mencari contoh format surat } \\
\text { permohonan pengajuan ijin operasional } \\
\text { tersebut. Kemudian menyelesaikan } \\
\text { penulisan surat tersebut, mengikuti } \\
\text { format. }\end{array}$ \\
\hline $\begin{array}{l}\text { Foto Copy Identitas } \\
\text { Pendiri (KTP) }\end{array}$ & $\begin{array}{l}\text { Tidak ada kendala yang } \\
\text { dihadapi. }\end{array}$ & Meminta $F C$ KTP tersebut. \\
\hline $\begin{array}{l}\text { Surat Keterangan } \\
\text { Domisili }\end{array}$ & $\begin{array}{l}\text { Belum memiliki surat } \\
\text { keterangan domisili. }\end{array}$ & $\begin{array}{l}\text { Meminta surat pengantar dari RT } \\
\text { kemudian ke RW kemudian ke } \\
\text { Kelurahan dan sampai di Kecamatan } \\
\text { meyerahkan surat pengantar tersebut. } \\
\text { Kemudian pihak Kecamatan akan } \\
\text { memberikan surat keterangan domisili } \\
\text { kepada lembaga. }\end{array}$ \\
\hline
\end{tabular}

\begin{tabular}{lllr}
\hline $\begin{array}{l}\text { Struktur Organisasi } \\
\text { dan }\end{array}$ & $\begin{array}{l}\text { Belum memiliki struktur } \\
\text { Tugasnya }\end{array}$ & $\begin{array}{l}\text { organisasi serta uraian } \\
\text { tugasnya secara terformat } \\
\text { dan tertulis. }\end{array}$ \\
& & & \\
& & & \\
\hline $\begin{array}{l}\text { Surat Perjanjian } \\
\text { Sewa Tanah }\end{array}$ & $\begin{array}{l}\text { Belum memiliki } \\
\text { perjanjian surat } \\
\text { gedung. }\end{array}$ & & \\
& &
\end{tabular}

Membuat struktur organisasi secara terformat dan tertulis, kemudian membuat job disc sesuai dengan tugas masing-masing.

Meminta surat perjanjian sewa tanah/ gedung kepada pihak yang berwenang, yang menjelaskan bahwa pihak lembaga benar-benar melakukan sewa kepada pihak yang memiliki tanah/ gedung tersebut.

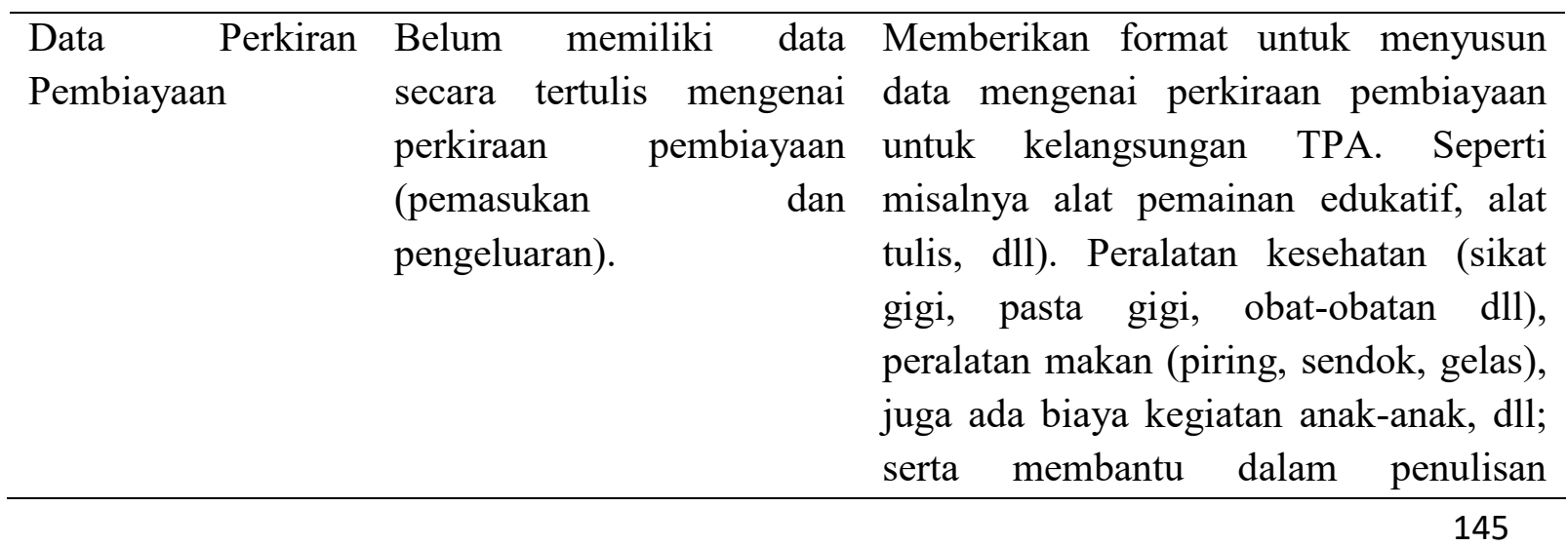




\begin{tabular}{|c|c|c|}
\hline & & $\begin{array}{l}\text { pemasukan dan pengeluaran biaya } \\
\text { kebutuhan TPA tersebut. }\end{array}$ \\
\hline $\begin{array}{l}\text { Standar } \\
\text { Penyelenggaraan } \\
\text { TPA }\end{array}$ & $\begin{array}{l}\text { Belum menyusun standar } \\
\text { penyelenggaraan TPA. }\end{array}$ & $\begin{array}{l}\text { Membantu dengan memberikan contoh } \\
\text { dan pengertian kepada pengelola tentang } \\
\text { Standar Pendidikan Anak Usia Dini. } \\
\text { Memberikan referensi sebagai acuan } \\
\text { dari Naskah Akademik Kajian } \\
\text { Kebijakan Kurikulum Pendidikan Anak } \\
\text { Usia Dini, Departemen Pendidikan } \\
\text { Nasional Badan Penelitian dan } \\
\text { Pengembangan Pusat Kurikulum } 2007 \\
\text { kepada Lembaga TPA. }\end{array}$ \\
\hline $\begin{array}{ll}\text { Salinan/copy } & \text { NPSN } \\
\text { (Nomor } \quad \text { Pokok } \\
\text { Sekolah Nasional) }\end{array}$ & Belum memiliki. & $\begin{array}{l}\text { Belum dapat diperoleh dari dinas } \\
\text { pendidikan, sebelum memiliki surat ijin } \\
\text { operasional sekolah. }\end{array}$ \\
\hline Kurikulum & $\begin{array}{l}\text { Belum memiliki kurikulum } \\
\text { yang jelas. }\end{array}$ & $\begin{array}{l}\text { Memberikan gambaran dan penjelasan } \\
\text { tentang kurikulum, memberikan contoh } \\
\text { kurikulum yang ada. }\end{array}$ \\
\hline Dokumentasi & $\begin{array}{l}\text { Tidak ada kendala yang } \\
\text { dihadapi. }\end{array}$ & $\begin{array}{l}\text { Menyimpan dokumentasi dan mencetak } \\
\text { menjadi foto. }\end{array}$ \\
\hline
\end{tabular}

Berdasarkan pada tabel.1, peneliti telah melakukan beberapa strategi. Dari surat permohonan yang masih dalam proses, peneliti sudah memberikan penjelasan kepada pihak lembaga bahwa isi surat permohonan tersebut adalah surat permohonan untuk mendirikan Taman Penitipan Anak. Akan tetapi, pihak lembaga belum dapat menyelesaikan surat permohonan tersebut dikarenakan masih ada hal lain yang dikerjakan. Peneliti kemudian membuat strategi dengan cara mencari contoh format surat permohonan pengajuan ijin operasional tersebut. Peneliti kemudian menyelesaikan penulisan surat tersebut.

Untuk syarat administratif yang meliputi fotokopi identitas pendiri, surat keterangan domisili dari kepala desa/lurah dan susunan pengurus dan rincian tugas, pihak lembaga sudah mencoba untuk menyelesaikannya. Pengelola mengalami kendala dalam mengurus surat domisili. Kendala yang dihadapi yaitu pihak lembaga merasa kesulitan untuk menemui pihak pengurus yang bersangkutan, yang mengurus surat prosedur untuk memperoleh keterangan domisili, sehingga membuat persiapan ijin operasional menjadi sedikit lama.

Dalam susunan pengurus dan uraian tugas yang ada di Lembaga Taman Penitipan Anak sudah dijelaskan. Peneliti membantu dalam penyelesaian penulisan struktur organisasi dan uraian tugas masing-masing. Berdasarkan data yang diperoleh, Rt merupakan pengelola TPA Bright Minds. Rt berusia 43 tahun pada tahun 2017 ini. Rt memiliki latar belakang pendidikan Sarjana Ekonomi (SE). Beliau bertugas sebagai pengelola dan menentukan 
kebijakan yang ada pada lembaga tersebut. Selain itu, beliau bertanggung jawab atas perkembangan anak didik, mempertanggungjawabkan bantuan yang diterima, menyampaikan laporan kepada Disdikpora dan Himpaudi Kecamatan Sidomukti, pembinaan terhadap guru, meneliti dan menandatangani administrasi publik. Ada pula Yk berusia 46 tahun pada tahun 2017 ini. Beliau memiliki latar belakang SMP, beliau sebagai pengasuh di TPA Bright Minds Salatiga. Mt berusia 42 tahun pada tahun 2017. Beliau memiliki latar belakang SMP, beliau sebagai pengasuh di TPA Bright Minds Salatiga. Nt berusia 50 tahun pada tahun 2017 ini. Beliau memiliki latar pendidikan SPG, beliau sebagai pengasuh di TPA Bright Minds Salatiga. Sebagai pengasuh, mereka bertugas untuk mengasuh anak-anak, memberikan stimulasi kepada anak-anak, juga memberikan pendidikan moral kepada anak. Misalnya, mengucapkan kata tolong, kata maaf, kata terimakasih. Ada pula $\mathrm{Na}$ sebagai pendidik sekaligus asisten Rt pengelola TPA tersebut. Na berusia 36 tahun pada tahun 2017. Beluai memiliki latar pendidikan Sarjana Teologi (S.Th). Beliau yang mengajar anak-anak dalam pembelajaran melalui bermain.

Mengenai surat perjanjian sewa tanah, pihak Lembaga Taman Penitipan Anak Bright Minds Salatiga sudah berusaha mencari surat perjanjian sewa tanah tersebut. Lembaga ini berdiri ditanah milik Sekolah Tinggi Teologi. Lembaga TPA Bright Minds sudah memperoleh surat perjanjian sewa tanah dari Sekolah Tinggi Teologi tersebut. Bahwa pihak TPA Bright Minds Salatiga benar-benar kontrak di tanah milik Sekolah Tinggi Teologi tersebut.

Dalam menyusun data mengenai perkiraan pembiayaan untuk kelangsungan TPA, pihak TPA meminta masukan kepada peneliti. Peneliti telah berusaha memberikan format untuk menyusun data mengenai perkiraan pembiayaan untuk kelangsungan TPA. Seperti misalnya alat pemainan edukatif, alat tulis, dll). Peralatan kesehatan (sikat gigi, pasta gigi, obat-obatan dll), peralatan makan (piring, sendok, gelas), juga ada biaya kegiatan anak-anak, dll. Peneliti membantu dalam penulisan pemasukan dan pengeluaran biaya kebutuhan TPA tersebut.

Lembaga Taman Penitipan Anak (TPA) ini memiliki beberapa kegiatan untuk menunjang tingkat pencapaian perkembangan anak. Adapula sarana prasarana yang ada di TPA tersebut untuk mendukung kegiatan bermain anak. Sebenarnya Lembaga TPA Bright Minds ini sudah melakukan standar penyelenggaraan TPA. Namun, Lembaga TPA tersebut belum memiliki acuan yang pasti dalam standar penyelenggaraan TPA tersebut. Sehingga, peneliti membantu dengan memberikan contoh dan pengertian kepada pengelola tentang Standar Pendidikan Anak Usia Dini. Peneliti juga memberikan referensi sebagai acuan dari Naskah Akademik Kajian Kebijakan Kurikulum Pendidikan Anak Usia Dini, Departemen Pendidikan Nasional Badan Penelitian dan Pengembangan Pusat Kurikulum 2007 kepada Lembaga TPA Bright Minds Salatiga. Dengan demikian, Lembaga TPA Bright Minds Salatiga telah menerapkan acuan dari Peraturan Menteri Pendidikan Nasional Nomor 58 Tahun 2009 Tanggal 17 September 2009.

Untuk beberapa lampiran yang ada seperti salinan/copy sertifikat NPSN pihak lembaga belum memperolehnya dikarenakan NPSN dapat diperoleh apabila lembaga sudah memiliki surat ijin operasional. Sedangkan lembaga TPA Bright Minds Salatiga belum memiliki surat ijin operasional. 
Lembaga Taman Penitipan Anak Bright Minds Salatiga ini menyusun kurikulum berdasarkan Permendikbud No 58 tahun 2009. Lembaga ini memberikan pembelajaran untuk anak melalui bermain. Mereka membuat RPPH mengacu pada indikator-indikator yang ada pada Permendikbud No 58 tahun 2009, menurut standar tingkat pencapaian pertumbuhan anak. Melihat rentang usia menjadi hal yang perlu diperhatikan menurut Rt. Dengan memperhatikan rentang usia, Rt mampu memberikan pembelajaran yang tepat bagi anakanak dan tidak membahayakan. Untuk pendokumentasian di lembaga ini dilakukan sendiri oleh Rt dan pendokumentasiannya disesuaikan dengan kebutuhan yang dibutuhkan.

Strategi yang dilakukan untuk mempersiapkan pengajuan ijin operasional TPA Bright Minds Salatiga yaitu:

1. Menyusun surat permohonan. Dengan mencari contoh format surat permohonan pengajuan ijin operasional tersebut. Kemudian menyelesaikan penulisan surat tersebut, mengikuti format.

2. Meminta FC KTP pengelola lembaga.

3. Meminta surat pengantar dari RT kemudian ke RW kemudian ke Kelurahan dan sampai di Kecamatan meyerahkan surat pengantar tersebut. Kemudian pihak Kecamatan akan memberikan surat keterangan domisili kepada lembaga.

4. Membuat struktur organisasi secara terformat dan tertulis, kemudian membuat job disc sesuai dengan tugas masing-masing.

5. Meminta surat perjanjian sewa tanah/ gedung kepada pihak yang berwenang, yang menjelaskan bahwa pihak lembaga benar-benar melakukan sewa kepada pihak yang memiliki tanah/gedung tersebut.

6. Mencari format untuk menyusun data mengenai perkiraan pembiayaan untuk kelangsungan TPA. Seperti misalnya alat pemainan edukatif, alat tulis, dll). Peralatan kesehatan (sikat gigi, pasta gigi, obat-obatan dll), peralatan makan (piring, sendok, gelas), juga ada biaya kegiatan anak-anak, dll; serta melakukan penulisan mengenai pemasukan dan pengeluaran biaya kebutuhan TPA.

7. Membantu dengan memberikan contoh dan pengertian kepada pengelola tentang Standar Pendidikan Anak Usia Dini. Memberikan referensi sebagai acuan dari Naskah Akademik Kajian Kebijakan Kurikulum Pendidikan Anak Usia Dini, Departemen Pendidikan Nasional Badan Penelitian dan Pengembangan Pusat Kurikulum 2007 kepada Lembaga TPA.

8. Memberikan gambaran dan penjelasan tentang kurikulum, memberikan contoh kurikulum yang ada.

9. Menyimpan dokumentasi dan mencetak menjadi foto.

Dengan melalukan beberapa strategi tersebut, peneliti dapat menyusun proposal yang dapat diajukan kepada pihak Dinas Pendidikan Kota Salatiga. Proposal yang diajukan tersusun dari: Bab I Pendahuluan (Latar Belakang Taman Penitipan Anak (TPA), Visi Taman Penitipan Anak (TPA), Misi Taman Penitipan Anak (TPA), Tujuan, Sarana Prasarana), Bab II (Pelaksanaan Kegiatan), Bab III (Pembiayaan), Bab IV (Permasalahan yang dihadapi), Bab V (Penutup), Lampiran (Profil TPA Bright Minds; Surat perjanjian sewa rumah; Surat keterangan domisili; Struktur organisasi, Uraian tugas pengurus; Biodata pengelola, pendidik dan pengasuh; Kurikulum ; Jadwal Kegiatan; Daftar sarana dan prasarana; Foto kegiatan). 


\section{PENUTUP}

\section{Kesimpulan}

Berdasarkan hasil wawancara kepada pihak Lembaga Taman Penitipan Anak Bright Minds Salatiga, sebelumnya belum mengetahui syarat penyelenggaraan Taman Penitipan Anak (TPA) dan mengalami kesulitan dalam penyusunan dokumen-dokumen dalam memenuhi persyaratan penyelenggaraan Taman Penitipan Anak (TPA). Setelah peneliti mengetahui persyaratan penyelenggaraan Taman Penitipan Anak (TPA) dan membantu dalam penyusunan dan persiapan ijin operasional TPA Bright Minds, saat ini pihak lembaga dapat memenuhi dokumen-dokumen yang diperlukan untuk memenuhi syarat penyelenggaraan Taman Penitipan Anak (TPA). Sehingga pihak lembaga dapat mengajukan proposal permohonan ijin operasional TPA Bright Minds Salatiga kepada Dinas Pendidikan Salatiga.

\section{Saran}

Peneliti memberikan beberapa saran berdasarkan hasil penelitian yaitu:

\section{Saran teoritis}

Penelitian ini menjabarkan mengenai persiapan ijin operasional TPA Bright Minds Salatiga. Sehingga penelitian ini dapat dijadikan acuan untuk penelitian selanjutnya.

\section{Bagi subjek penelitian}

Dari penelitian ini diharapkan subjek dapat belajar lebih lagi untuk mereka dapat berinovasi memberikan suatu pembelajaran kepada lembaga TPA. Subjek juga dapat mengetahui bagaimana persiapan pengajuan ijin operasional sebuah Lembaga Taman Penitipan Anak.

\section{Bagi peneliti selanjutnya}

Penelitian ini hanya mengkaji bagaimana persiapan pengajuan ijin operasional Taman Penitipan Anak (TPA), maka untuk penelitian selanjutnya peneliti dapat melanjutkan mengenai pengajuan ijin operasional Taman Penitipan Anak (TPA) untuk diproses pengajuannya kepada Dinas Pendidikan.

\section{DAFTAR PUSTAKA}

Arifin, Anwar. 1984. Strategi Komunikasi. Bandung: Armilo

Aprillia, Sherlly. 2015. Pelaksanaan Pengasuhan Anak UsiaDini Di Tempat Penitipan Anak (TPA) Dharma Yoga Santi Yogyakarta. Skripsi (diterbitkan). Yogyakarta: Fakultas Ilmu Pendidikan Universitas Negri Yogyakarta.

Hapidin. 2003. Manajemen Penyelenggaraan Lembaga Pendidikan Anak Usia Dini. Jakarta: Pusdiani Press.

http://library.binus.ac.id/eColls/eThesisdoc/Bab2/2013-1-00190-MN\%20Bab2001.pdf, diakses pada 20 Januari 2019 
http://news.liputan6.com/read/2050600/tak-memiliki-izin-kegiatan-playgroup-saint-monicadihentikan, diakses pada 19 Desember 2017

https://www.kompasiana.com/afifahwindyaningrum/tahapanpendirian,paud_54f70515a3331197238b45a4, diakses pada 19 desember 2017

http://disdik.ciamiskab.go.id/wp-content/uploads/2018/04/Pendirian-PAUD-dan-PNF.pdf, diakses pada 19 Januari 2019

Hunger, David dan Wheelen, Thomas L. (2003) Manajemen Strategi, (Yogyakarta: Andi)

Keputusan Kepala Disidikpora Kota Salatiga Nomor 800/0514/101, tanggal 2 November 2016 tentang Penerapan Standar Operasional Prosedur (SOP) Pelayanan Perizinan Pendidikan Non Formal pada Dinas Pendidikan Pemuda dan Olahraga Kota Salatiga

Kusumawati, Desi. 2017. Manajemen Sarana Prasarana di Baby's Home Salatiga. Jurnal Scholaria, Vol. 7 No 1

Peraturan Menteri Pendidikan dan Kebudayaan Nomor 84 tahun 2014 tentang Pendirian Satuan Pendidikan Anak Usia Dini

Peraturan Menteri Pendidikan Nasional Republik Indonesia Nomor 58 tahun 2009

Sugiyono. 2010.Metode Penelitian Pendidikan (Pendidikan Kuantitatif, Kualitatif dan R\&D). Bandung: Alfabeta

Suharti. 2018. Manajemen Pendidikan Anak Usia Dini (PAUD) dalam Rangka Meningkatkan Mutu Pembelajaran (Studi pada PAUD Negeri Pembina Curup dan PAUD Pertiwi Kabupaten Rejang Lebong). TADBIR : Jurnal Studi Manajemen Pendidikan 2 (1). http://e-journal.uajy.ac.id/4821/3/2MIH01448.pdf, diakses pada 20 Januari 2019

Syamsuddin,Erman. 2015. Nspk Norma, Standar, Prosedur, Dan Kriteria Petunjuk Teknis Penyelenggaraan Taman Penitipan Anak. Jakarta: Direktorat Pembinaan Pendidikan Anak Usia Dini Direktorat Jenderal Pendidikan Anak Usia Dini dan Pendidikan Masyarakat Kementerian Pendidikan dan Kebudayaan 